\title{
Bacterial Biofilms and Suspended Matter in the Sewer System: Examination at Various Scales
}

\author{
J. Houhou ${ }^{1,2^{*}}$, B.S. Lartiges ${ }^{1,3}$, C. Mustin ${ }^{4}$, J. Ghanbaja ${ }^{5}$, Z. Khalil ${ }^{6}$ \\ ${ }^{1}$ University of Lorraine, LIEC (Laboratoire Interdisciplinaire des Environnements Continentaux), UMR CNRS 7360, 54501Vandoeuvre-les- \\ Nancy, France \\ ${ }^{2}$ Environmental Health Research Laboratory (EHRL), Faculty of Sciences V, Lebanese University, Nabatieh, Lebanon
}

${ }^{3}$ University of Toulouse (Paul Sabatier), Geosciences Environnement Toulouse (UMR CNRS-UPS-IRD), 14 Av. E. Belin, 31400 Toulouse, France

${ }^{4}$ University of Lorraine, LIEC (Laboratoire Interdisciplinaire des Environnements Continentaux), UMR CNRS 7360,Campus Sciences, B.P. 70239, F-54506 Vandœuvre-lès-Nancy, France

\author{
${ }^{5}$ Institut Jean Lamour, CNRS-Université de Lorraine, Boulevard des Aiguillettes, BP 70239, 54506 Vandoeuvre-Les-Nancy, \\ France \\ ${ }^{6}$ Inorganic and Organometallic Coordination Chemistry Laboratory, Faculty of Sciences I, LebaneseUniversity, Lebanon
}

\begin{abstract}
The nature and architecture of suspended matter (SM) and bacterial biofilms collected in Greater Nancy sewer system were investigated alongtwo years. Samples were taken from three sewer sections from upstream to downstream. Samples characterizations were conducted at millimetric scale using Confocal Laser Scanning Microscope (CLSM) and nanometric scale using Transmission Electron Microscopy (TEM). Several physicochemical and bacterial parameters were studied such as dissolved organic carbon (DOC), total bacteria, total suspended solid (TSS), volatile matter (VM) and particle size distribution of SM. The concentration of DOC decreases along the sewer from upstream to downstream. No clear evolution was found in total bacterial number along sewer. TSS was mainly composed of VM, and was found to decrease along the sewer. The temporal evolution of wastewater quality at a given sampling site shows no obvious change in total bacterial number. DOC and TSS concentrations were highest at midday, and decreases to reach their lowest value at 6h00. The volume size distribution of SM evolves from a multimodal distribution at upstream to a monomodal one at downstream of the sewer system. This decrease of particle size along sewer is likely related to the settling of SM and not to the degradation of suspended organic matter. Microscopic investigations indicated that SM and biofilm have similar composition (bacterial cells, extracellular polymeric substances (EPS), cellulose fibers, cell lyses detritus, organo-mineral detritus and mineral particles). Nevertheless, they have different $3 D$ architectures. In SM, cellulose fibers form a skeleton for bacterial aggregates and biomass formation, within which bacteria may biodegrade fibers. The structural quantification revealed an open and patchy SM with 0.8 as porosity and $45 \%$ as coverage surface. Whereas, biofilms were more compact and denser than SM (porosity 0.55 , coverage surface 92\%). Water channels were identified through the biofilm depth with a decrease of areal porosity from the top to the bottom. Cellulose fibers were embedded in EPS matrix andbacterial division participates to biofilm growth. Viruses including bacteriophages were encountered within biofilms which may be considered as a potential reservoir of pathogenic viruses, especially during combined sewer overflows. Exchanges between SM and biofilms have been proven. On one handby the transfer of cellulose fibers from sewage to biofilms. On the other hand by the detachment of some parts from mature biofilms and their transport in sewage.
\end{abstract}

Keywords: Suspended matter, sewer biofilm, TEM, CLSM, cellulose fiber, particle size, sedimentation

\section{Introduction}

Until recently, the sewer system was considered as a drainage system used essentially to evacuate wastewater from cities. It is now recognized as a biophysicochemical reactor ${ }^{[1,2,3,4]}$ in which sewage, bacterial biofilms and sediments may interact to provide a primary stage of wastewater treatment system ${ }^{[4,5]}$.Thus, the concentrations of organic matter (OM), chemical oxygen demand (COD), and dissolved oxygen (DO) in sewage were found to evolve during wastewater transport ${ }^{[4,5,6,7]}$. In addition, the formation of hydrogen sulfide and its reaction with dissolved heavy metals illustrate such a role ${ }^{[8,9,10]}$.

Several studies indicated the evolution of bacterial biofilms in sewer pipes and its implication in the wastewater treatment ${ }^{[11,12]}$. Bacterial biofilms uptake DO, OM, ammonium and nitratefrom bulk sewage ${ }^{[3,13,14,15]}$. These solutes are converted to biomass ${ }^{[1,16]}$ leading to biofilms growth $^{[5]}$ and inducing a change in biofilms structure. Moreover, the physicochemical conditions in the sewer (flow velocity, anoxic and septic conditions) may influence the biofilm architecture ${ }^{[17]}$. Mature biofilms may detach from pipe walls and re-suspend into sewage, increasing the amount of suspended matter (SM) in wastewater ${ }^{[18,19]}$.

Past studies showed the evolution of SM in sewer network. Suspended organic matter may undergo fermentation and hydrolysis to give dissolved matter ${ }^{[5]}$, the mineralogical nature of suspended minerals evolves along sewer, and SM may also be attached to sewer biofilms or settle as sediments $[1,20,21]$

Few studies have been carried out to characterize the uptake of suspended organic matter by bacterial biofilmsand its transformation to biomass ${ }^{[5,18]}$. Nevertheless, it still unclear how these OM are structured as solid matter within biofilms. The main objective of this work was to characterize the 


\section{International Journal of Science and Research (IJSR) \\ ISSN (Online): 2319-7064}

Index Copernicus Value (2015): 78.96 | Impact Factor (2015): 6.391

architecture of sewer biofilms and SM, in order to improve the knowledge about their components, their architectures, and to underline the exchange between biofilms and SM. Thus, transmission electron microscopy (TEM) on resinembedded samples and confocal laser scanning microscopy (CLSM) were used. TEM imaging at nanoscale gives information about the spatial distribution of microorganisms within the biofilm matrix. CLSM allows samples characterization at microscale under hydrated conditions, using a non-destructive optical sectioning within samples ${ }^{[22,23]}$, allowing the reconstruction of the 3D structures of samples. Moreover, some physicochemical and biological parameters of sewage were characterized such as dissolved organic carbon (DOC), total bacterial number, total suspended solid (TSS), volatile matter (VM) and the particle size distribution of SM.

\section{Experimental Section}

\section{1) Study Area}

Samples were collected from the sewer network of Greater Nancy urban community, a city of about 270 000inhabitants located in north-eastern France, lies on both banks of Meurthe river with a total catchment area of $193 \mathrm{Km}^{2}(144$ $\mathrm{km}^{2}$ on left bank). The sewage collecting system comprises $950 \mathrm{~km}$ of pipes, $250 \mathrm{~km}$ of them being man-entry sewer (pipe diameter $\geq 1.2 \mathrm{~m}$ ).

The flow of wastewater in sewer pipes is turbulent $(\operatorname{Re}=4 \times$ $10^{5}$ ) with $0.4 \mathrm{~m} / \mathrm{s}$ as average velocity. Three sewer sections, each with 5 sampling sites from upstream to downstream of the sewer network, were selected for this study. These sites represent the various lands in the urban community (residential, commercial, industrial, high school, and hospital). On a general basis, the upstream sampling sites only receive domestic wastewater from a separated sewer, impacted either by hospital or industrial wastewaters. Whereas, the downstream sampling sites mainly receive sewage from high density residential areas and small businesses through a combined sewer.

\section{2) Sample collection and preparation}

Eight sampling campaigns of Grab-samples of sewage and biofilms were conducted in dry weather conditions. Sewage characteristics such as temperature, $\mathrm{pH}$, conductivity, dissolved oxygen concentration, redox potential and turbidity were measured immediately upon sampling and illustrated in a previous work ${ }^{[20]}$. Part of the sewage was filtered on site, and the filtrate was stored at $4^{\circ} \mathrm{C}$ in $65 \mathrm{~mL}$ glass bottles until DOCanalysisusing a Dohrman 190 analyzer. $100 \mathrm{~mL}$ of wastewater were stored in a sterile bottle at $4^{\circ} \mathrm{C}$ to enumerate the total bacteria. About $1 \mathrm{~L}$ of sewage was taken to measure the SM size distributions. Two $24 \mathrm{~h}$ campaigns were conductedin a two different sampling sites in order to evaluate the temporal variationsof wastewater characteristics.

Furthermore, five biofilm samples were collected from different manholes by gentle scraping of collectors inner walls, andeach biofilm was divided into two aliquots in hermetic tubes and stored at $4^{\circ} \mathrm{C}$ for microscopic investigations.
About $20 \mathrm{~L}$ of sewage were brought back to the laboratory in a polyethylene jerrycans. After gentle end-over-end mixing of the jerrycans, $20 \mathrm{~mL}$ of sewage corresponding to biofilm sampling points were taken and allowed to settle in a test tube for $2 \mathrm{~h}$. Settleable fractions were then aliquoted in close hermetic tubes and stored at $4^{\circ} \mathrm{C}$ for SM microscopic observations. $1 \mathrm{~L}$ of sewage was centrifuged in polyethylene bottles at $15000 \mathrm{~g}$ for $30 \mathrm{~min}$ (Sorvall_EvolutionRC). The mass of the TSS was then determined by drying an aliquote of centrifuged sewage at $105^{\circ} \mathrm{C}$ for $12 \mathrm{~h}$, and the VM mass was obtained by further heating the same samples at $550^{\circ} \mathrm{C}$ for $4 \mathrm{~h}$. All samples were analyzed in triplicate.

\section{3) Total bacteria enumeration}

Total bacteria were enumerated in 35 wastewater samples using the most probable number (MPN) technique. The Luria Bertani (LB, Sigma ${ }^{\circledR}$ ) medium sterilized by autoclaving at $120^{\circ} \mathrm{C}$ during 20 min was used as growth medium. 10-fold serial dilutions in sterile $\mathrm{NaCl} 8 \%$ were applied to $10 \mathrm{~mL}$ aliquots taken from wastewater. $25 \mu \mathrm{L}$ aliquots of each dilution were then inoculated in $200 \mu \mathrm{L}$ of culture medium which were introduced in sterile microplates wells. The number of replicates was 40 for each dilution. After inoculation, MPNmicroplates were incubated at $24^{\circ} \mathrm{C}$ during 48 hours. After incubation, the optical density of inoculated wells was measured at $620 \mathrm{~nm}$ (BioTek Instrument Inc.) and the MPN wasdetermined using MPN calculator software 4.04(EPA).

\section{4) Measurement of particle size distribution of suspended matter}

SM particle size measurements were carried out immediately after the return to the laboratory using a Malvern MasterSizer particle size analyzer with a 1.2-600 $\mu \mathrm{m}$ particle size detection range. To avoid multiple scattering in the measurement cell, SM was diluted with the supernatant of centrifuged wastewater $(15000 \mathrm{~g}$ for $30 \mathrm{~min}$, Sorvall $^{\circledR}$ Evolution RC) to yield suspended solid concentrations varying from 1 to $9 \mathrm{mg} / \mathrm{L}$. The dilution was obtained in a standard $1 \mathrm{~L}$ baffled reactor $(90 \mathrm{~mm}$ diameter, $150 \mathrm{~mm}$ high), and the suspension was stirred with a $15 \mathrm{~mm}$ $\times 54 \mathrm{~mm}$ blade positioned at $1 / 3$ of the height of the reactor. An adjustable-speed motor (Janke\&Kundel RW 20 DZM) was used to provide stirring rates of $100 \mathrm{rpm}$, which corresponds to $135 \mathrm{~s}^{-1}$ as averaged velocitygradient $G^{[24]}$.

The agitated suspension was continuously withdrawn from the bottom of the reactor, and passed through the analyzer beam with a peristaltic pump located downstream the measurement cell, before being recycled to the reactor. Pumping flow rates of $35 \mathrm{~mL} / \mathrm{min}$, and a plastic tubing of $4.6 \mathrm{~mm}$ internal diameter, were selected. Size measurements were averaged over $1 \mathrm{~s}$ and taken every $2 \mathrm{~s}$ to allow a complete renewal of matter present in laser beam. Results obtained are given in percentage of particle volume versus floc diameter $(\mu \mathrm{m})$.

\section{5) Structure investigations ofsuspended matter and bacterial biofilm}

The geometrical structures of bacterial biofilms and SM were characterized using a CLSM and TEM.

Confocal microscopy is a non-destructive method, allowing in situ three-dimensional observation of hydrated samples at 


\section{International Journal of Science and Research (IJSR) \\ ISSN (Online): 2319-7064}

Index Copernicus Value (2015): 78.96 | Impact Factor (2015): 6.391

microscale. It allows the examination of the complex interior-structure of stained samples with digital twodimension image acquisitions in z-axis (optical sections), with a high resolution. Before observations, samples were stained with an Acridine-Orange buffered solution (SigmaAldrich, $22 \mu \mathrm{M}$ AO, $5 \mathrm{mM}$ EDTA, $0.15 \mathrm{M} \mathrm{NaCl}, 0.1 \mathrm{M}$ phosphate-citrate buffer [pH 6]). Acridine orange behaves differently in the presence of DNA and RNA: it exhibits a maximum fluorescence emission at $525 \mathrm{~nm}$ (green) for an excitation wavelength of $502 \mathrm{~nm}$ when the dye fits between both strands of the double helix, whereas, when bound to RNA, it gives a maximum emission at $650 \mathrm{~nm}$ (red) when excited at $460 \mathrm{~nm}^{[25,26]}$. This fluorochrome has also been widely used for visualizing mucopolysaccharid acids and glycolyzatedproteins ${ }^{[27]}$. The samples were stained with 100 $\mu \mathrm{L}$ of acridine orange buffered solution during $30 \mathrm{~min}$ at room temperature in the dark, and then washed 3 times with ultra-pure water (MilliQ-plus) to remove excess of dye. Samples were placed in glass-bottom dishes (WillCo-Dish®, $\emptyset 22 \mathrm{~mm})$, were observed with an inverted light microscope (NIKON TE 2000 U) equipped with a confocal head (Radiance 2100 Rainbow, Biorad). Objectives with magnification $\times 4, \times 20, \times 40$ and $\times 60$ were used to explore samples at different scales. The $488 \mathrm{~nm}$ and $457 \mathrm{~nm}$ lines of an argon ion laser, close to the excitation maxima of acridine orange, were used as light sources. The fluorescence signal of stained bacteria and exopolymers were recorded in the $530-560 \mathrm{~nm}$ frequency range andover $600 \mathrm{~nm}$, respectively. Image stacks $\left(512 \times 512\right.$ pixel $^{2}$, corresponding to 344510 $\mu \mathrm{m}^{2}$ ) weregenerated using LaserSharp2000 ${ }^{\mathrm{TM}}$ software (BioRad Cell Science Division). During sample sectioning, the line by line excitation mode (Lambda-Strobing) was used to reduce bleed-through.

Furthermore, MacBiophotonics ImageJ software (NIH, Bethesda, Maryland, USA) was used to calculate the areal porosity, the average porosity and the coverage rate $(\%)$ of $\mathrm{SM}$ and bacterial biofilm. Optical sections were thresholded and transformed to binary images before the calculation ofstructural parameters.For each optical section, areal porosity was calculated as the ratio of the void area to the total area of the image. The coverage rate of sample to the CLSM field view was determined after $\mathrm{z}$ projection of all optical sections; it was calculated as the ratio of full pixels to the total area of field view.

Bacterial biofilm and SM structures were also characterized at the nanoscale using a Philips CM20 TEM. Resinembedded samples were prepared for TEM observation. The samples, first fixed with glutaraldehyde and osmiumtetroxide, were passed through stepwise acetone dehydration,before being impregnated in a graded series ofepoxy resin monomer in acetone solutions, and finallypolymerized in molds at $60{ }^{\circ} \mathrm{C}$ for $24 \mathrm{~h}^{[28]}$. Sections $(100 \mathrm{~nm}$ thick) were cut on a ReichertOM U2 ultramicrotome with a diamond knife, stainedwith lead citrate and uranyl acetate, and placed oncopper grids for TEM examination.

\section{Results and Discussion}

\section{1) Enumeration of total bacteria}

Total bacteria in sewage were enumerated using the MPN method. Figure 1 illustrates the evolution of the total bacterial number along the three sewer sections (Fig. 1a, 1b and 1c) and for one diurnal cycle (Fig. 1d). Interestingly, no significant evolution of bacterial number was noticedfrom the upstream to thedownstream of all sewers sections. In fact, this can be related to the absence of limiting factor for bacterial growth in sewage. Several studies showed that the food/microorganisms ratio is relatively high in wastewater and the concentrations of OM and DOC does not influence the bacterial growth ${ }^{[1,3]}$.

The total number of bacteria along sewer sections ranges between $10^{5}$ and $10^{7}$ bacteria/mL(Fig. $1 \mathrm{a}, 1 \mathrm{~b}$ and $1 \mathrm{c}$ ). These values are similar to those found in literature ${ }^{[29,30]}$

$\left(5.6 \times 10^{6}\right.$ and $2.8 \pm 1.8 \times 10^{7}$ bacteria $\left./ \mathrm{mL}\right)$. The lowest total bacterial number was obtained at the CHU sampling site (Fig. 1a), which can be attributed to bacterial lyses by the antibiotics discharged in the sewer system from the hospital. Moreover, monitoring of total bacteria for one diurnal cycle (Fig. 1d) showed a weak evolution. Total bacterial number was $2 \times 10^{5}$ bacteria/mL at $08 \mathrm{~h} 15$. It decreases to reach $2 \times$ $10^{4}$ bacteria/mL at midday. Then, itre-increases to reach the initial value at $14 \mathrm{~h} 00$. At evening (18h00), the total bacterial number decreases to reach $1.6 \times 10^{4}$ bacteria $/ \mathrm{mL}$, to reincrease later to reach $2.7 \times 10^{5}$ bacteria/mL at $22 \mathrm{~h} 00$. The raise of total bacterial number at midday and at night may correspond to the use of toilets after lunch and dinner.

\section{2) Spatial evolution of suspended and dissolved organic matter}

Figure 2 illustrates the spatial evolution of DOC (Fig. 2a, 2b and 2c), TSS and VM (Fig. 2d, 2e and 2f) from upstream to downstream of the three sewer sections. Values showed that the highest concentrations of DOC (gray column) are in the upstream of sewers, whereas the lowest concentrations are in the downstream. A single clear decrease was found along the sewer in the section 1 (Fig. 2a). Two reasons can explain the decrease of DOC concentrations. On one hand, DOC may be assimilated by the bacterial biofilm, leading to the growth of biofilm biomassas evoked in previous studies ${ }^{[1,5]}$. On the other hand, the decrease of DOC along the sewer may correspond only to a simple dilution by clear water, and not to a biophysicochemical process.

In fact, the identification and the quantification of water sources in sewer using isotopic signature of water molecules $\left(\delta^{18} \mathrm{O}\right.$ and $\left.\delta \mathrm{D}\right)$ proves the infiltration of clear water (shallow aquifer) and the percolation of rainwater within sewer system through pipe crucks ${ }^{[31,32]}$.

Impoverishment of stable isotopes in wastewater (inset Fig. $2 \mathrm{a}$ and $2 \mathrm{~b}$ ) appears clearly along sewer and gives a dilution factor between each point ${ }^{[31]}$. Thus, dilution factors may be used to correct the measured concentration of DOC (Fig. 2a and $2 \mathrm{~b}$ white column). 


\section{International Journal of Science and Research (IJSR) \\ ISSN (Online): 2319-7064}

Index Copernicus Value (2015): 78.96 | Impact Factor (2015): 6.391
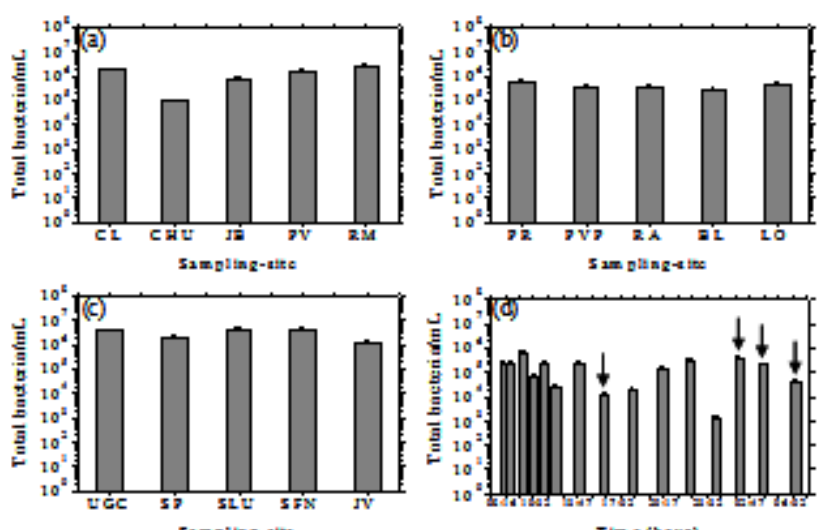

Figure 1(a, b, c): evolution of total bacterial number along the sewer sections 1, 2 and 3 respectively. (d) Evolution of total bacterial number during a diurnal cycle. Black arrows indicate the release of storm water
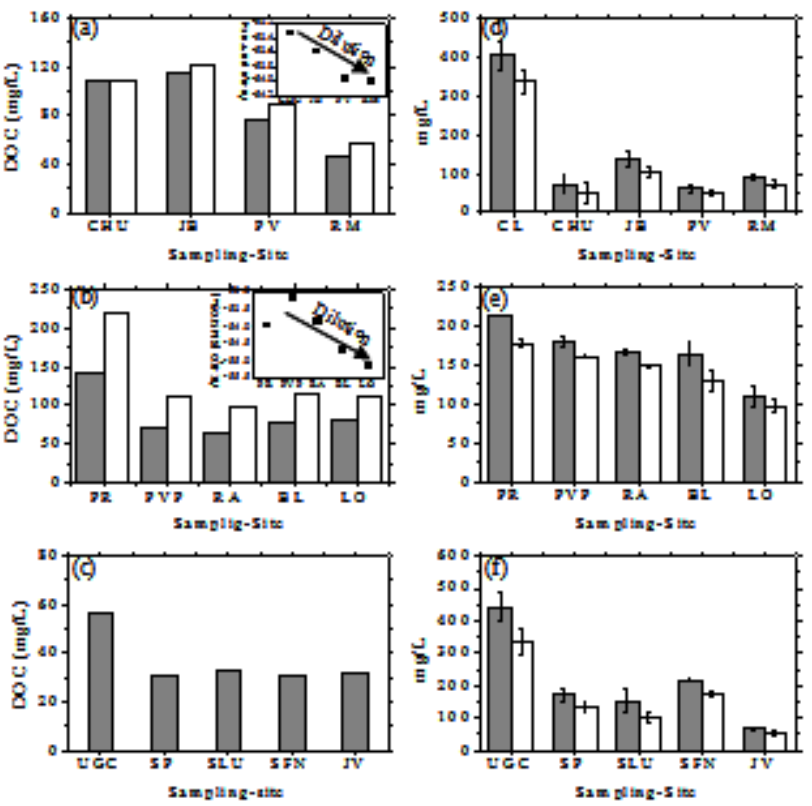

Figure 1(a, b and c): evolution of dissolved organic carbon (DOC) along the sewer in sewer sections 1, 2 and 3, respectively. Insets in Fig. $a$ and $b$ show the evolution of $\delta^{2} \mathrm{H}-\mathrm{H}_{2} \mathrm{O}$ and the dilution of wastewater along the sewer by groundwater infiltration (Gray column: measured DOC, white column: corrected DOC by dilution factors). ( $d$, e and f) evolution of total suspended solid (TSS: gray column) and volatile matter (VM: white column) along sewer.

Furthermore, TSS and VM concentrations follow the same trend of DOC (Fig. 2d, 2e and 2f). On one hand, the decrease of TSS and VM concentrations can be related to the degradation of particulate OM along sewer ${ }^{[5,32,33]}$. On the other hand, this decrease may come from the sampling protocol. In fact, grab-samples were taken from the wastewater system, and SM may settle down along sewer, leading to a decrease in TSS and VM concentrations. Michelbach ${ }^{[34]}$ indicated that in dry weather under low flow velocity $(14 \mathrm{~L} / \mathrm{s})$, organic solids will settle down giving muddy sediments, and proved at laboratory-scale that more than $80 \%$ of suspended particles had a settling velocity higher than $0.28 \mathrm{~cm} / \mathrm{s}$.
In all sampling sites, VM represents $80 \pm 9 \%$ of TSS. This result is similar to those found in literaturefor suspended solid collected in dry weather ${ }^{[34]}$.

3) Temporal evolution of suspended and organic matter Figure 3 illustrates the temporal evolution of DOC (Fig. 3a), TSS and VM (Fig. 3b) in wastewater for one diurnal cycle. DOC concentration increases from the morning to the midday to reach $160 \mathrm{mg} / \mathrm{L}$, unlike TSS and VM. After $14 \mathrm{~h} 00$, DOC concentration decreases to reach $12 \mathrm{mg} / \mathrm{L}$ at 06h15. TSS and VM had similar trend than DOC. Lowest concentrations of DOC, TSS and VM were measured at $16 \mathrm{~h} 00$ and after midnight. These low values were due to thedilution of sewage by discharged storm water in the sewer system from retention basin, as mentioned above ${ }^{[31]}$. $\mathrm{SM}$ in stored rainwater was allowed to settle down leading to the decrease in TSS and VM concentrations ${ }^{[35]}$.

\section{4) Suspended matter size distribution}

The particles sizes of SM were measured along the three sewer sections using Malvern MasterSizer particle size analyzer (Table 1). Values range between 29 and $167 \mu \mathrm{m}$, which are similar to those illustrated in literature ${ }^{[36,37]}$. Average values of particles sizes obtained at each sewer section were $47 \pm 27,74 \pm 53$, and $129 \pm 42 \mu \mathrm{m}$.

Table 1: Size of largest particles $(\mu \mathrm{m})$ obtained at each sampling-site

\begin{tabular}{|c|c|c|c|c|c|}
\hline Site 1 & Size & Site 2 & size & Site 3 & Size \\
\hline$\underline{C L}$ & 167 & $\underline{P R}$ & 161 & $\underline{U G C}$ & - \\
\hline$\underline{C H U}$ & 33 & $\underline{P V P}$ & 130 & $\underline{\text { SP }}$ & 29 \\
\hline$\underline{J B}$ & 68 & $\underline{R A}$ & 136 & $\underline{S L U}$ & 32 \\
\hline$\underline{P V}$ & 54 & $\underline{B L}$ & 160 & $\underline{S F N}$ & 82 \\
\hline$\underline{R M}$ & 49 & $\underline{L O}$ & 57 & $\underline{J V}$ & 43 \\
\hline
\end{tabular}
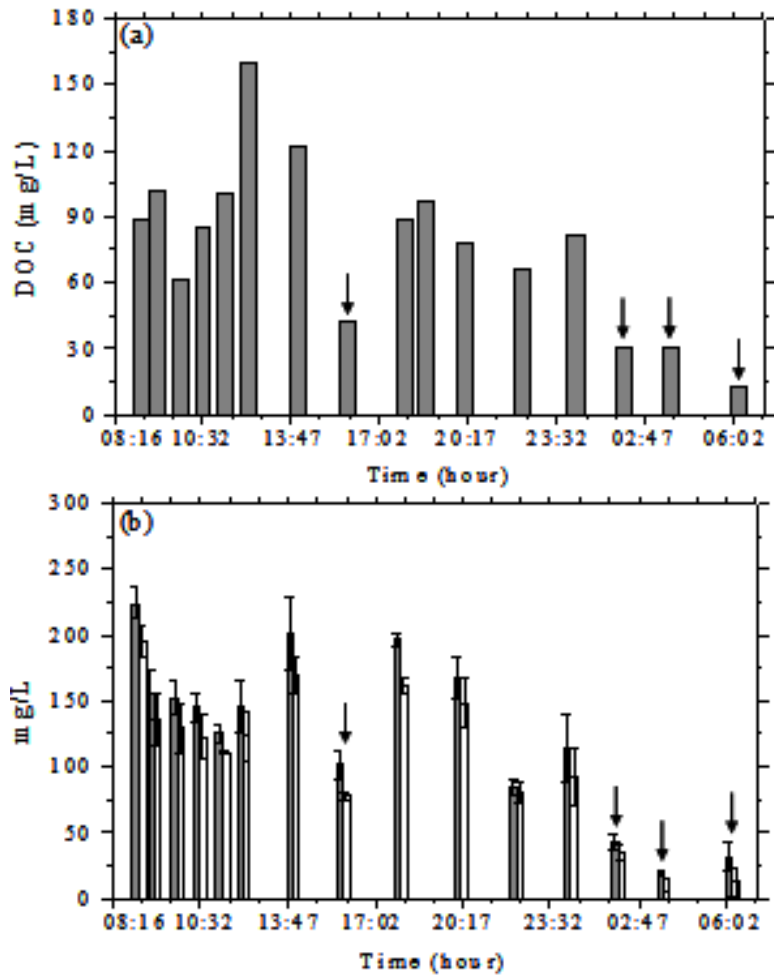

Figure 3: Temporal evolution of dissolved organic carbon (DOC) (a) total suspended solid (TSS: column gray) (b) and 


\section{International Journal of Science and Research (IJSR) \\ ISSN (Online): 2319-7064}

Index Copernicus Value (2015): 78.96 | Impact Factor (2015): 6.391

volatile matter (VM: while column) (b) for one diurnal cycle. Black arrows indicate the release of stormwater.
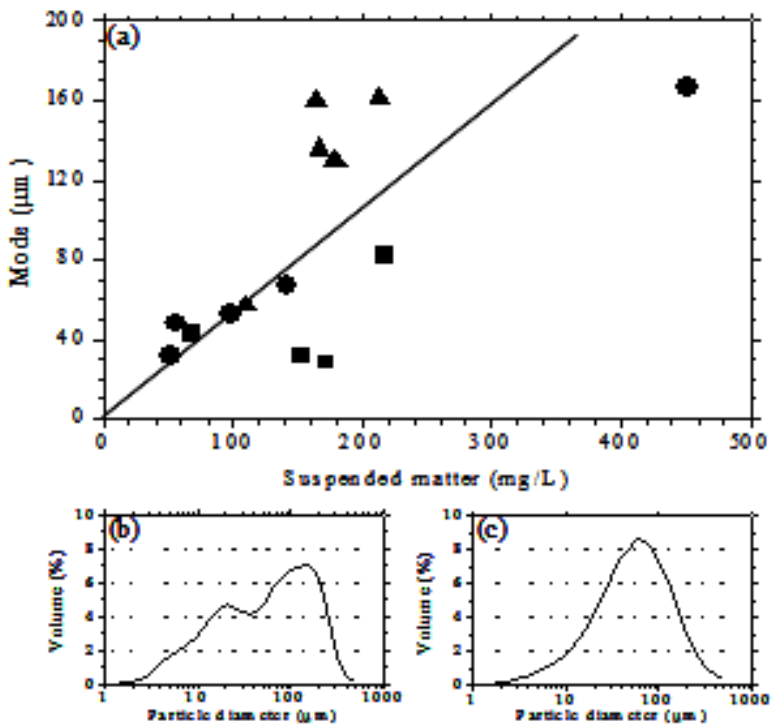

Figure 4: a) Relationship between larger particles (mode $\mu \mathrm{m})$ and the concentration in TSS for samples collected at sewer sections $1(\bullet), 2(\bullet)$ ), and 3( $\boldsymbol{\Delta}$ ). (b and c) Examples of particle size distribution of suspended matter in upstream

(b) and downstream (c) of sewer system.

The particle sizes in all sewer sections appear to be proportional to the concentration of TSS (Fig. 4a). Moreover, the size distribution of SM evolves along the sewer system. In upstream (Fig. 4b), the volume size distribution is multimodal and suspended particles have different ranges of particle sizes (3-6, 20-30, and 130-160 $\mu \mathrm{m})$, corresponding to different types of discharged matters in the sewer upstream such as toilet paper, excrement and vegetablespieces $^{[34]}$. The volume size distributions become bimodalin the middle of the sewer (30-50 and 100-140 $\mu \mathrm{m})$. Whereas, it is monomodal $(40-60 \mu \mathrm{m})$ in downstream, with a slight skewness toward smaller particle sizes (Fig. 4c).

Thus, the sizes of SM evolve along the sewer to give smaller aggregates. This evolution may be related to the physical disaggregation, chemical and bacterial decomposition of SM during theirtransport, and to the settling down of large particles. At the end, smaller homogeneous particles remain suspended in wastewater.

\section{5) Microscopical speciation of suspended matter}

Nine suspended matter from downstream sampling points were collected. Their architectures have been explored at micrometer and nanometer scales using CLSM and TEM, respectively. Figure 5a illustrates a 2D image of a SM floc characterized by CLSM(objective $\times 4$, zoom 1.5). Whereas, figures $5 \mathrm{~b}, 5 \mathrm{c}$ and $5 \mathrm{~d}$ (objective $\times 60$, zoom 3 ) are projections along $\mathrm{z}$-axis (central image), y-axis (bottom image), and $\mathrm{x}$-axis (right image) of image stack recorded by the confocal microscope.

Fluorescence's recorded from EPS and bacteria were combined together before projection. The red color corresponds to the EPS and the green one represents bacterial cells. Consequently, yellow indicates colocalization between microbial cells and EPS.
Figure 5a shows a typical 2D observation of SM which is composed of elongated fibers (in blue) with a diameter range between $10 \mu \mathrm{m}$ and $20 \mu \mathrm{m}$, forming a skeleton-like structure at which bacterial clusters (in green) were aggregated. Cluster diameters range from $20 \mu \mathrm{m}$ to $250 \mu \mathrm{m}$. Skeleton fibers may correspond to cellulose fibers from toilet paper discharged in the sewer. This hypothesis is proven after the observation of disaggregated toilet paper using an optical microscope, showing fibers with $10-25 \mu \mathrm{m}$ as diameter. This may be related to thelocal flushing down of the toilet paper. Suchhabit can certainly impact the sewer functioning as itwas established that about $15 \%$ of sewer solids correspondto toilet paper in $\mathrm{UK}^{[38]}$.

Furthermore, figure 5bshows a detailed characterization of a cluster from figure 5a. This cluster is composed of bacterial cells (green), embedded in an EPS matrix (red), forming a biomass using cellulose fibers as substratum.

Some SM contains filamentous bacteria (Fig. 5c) with a rod shape (diameter 1.5-2 $\mu \mathrm{m} /$ length2-4 $\mu \mathrm{m}$ ). This observation was previously illustrated by Æsøy ${ }^{[17]}$, showing the growth of filamentous bacteria (sphaerotilusnatans) in a synthetic wastewater.Structure quantification of SM (Fig. 5c) gives $45 \%$ as coverage surface and 0.8 as arealporosity.

Moreover, figure 5d shows an aggregate with a completely different structure, comparing to those observed. It appears more compact than that illustrated in figure $5 \mathrm{c}$, with $78 \%$ as surface coverage of 0.5 as areal porosity. Moreover, this SM contains fungi within their structure (inset Fig. 5d), suggesting a detachmentfrom bacterial biofilm ${ }^{[39,40]}$.Thus, biofilm may be detached from collector walls and released into wastewater ${ }^{[41,42]}$.
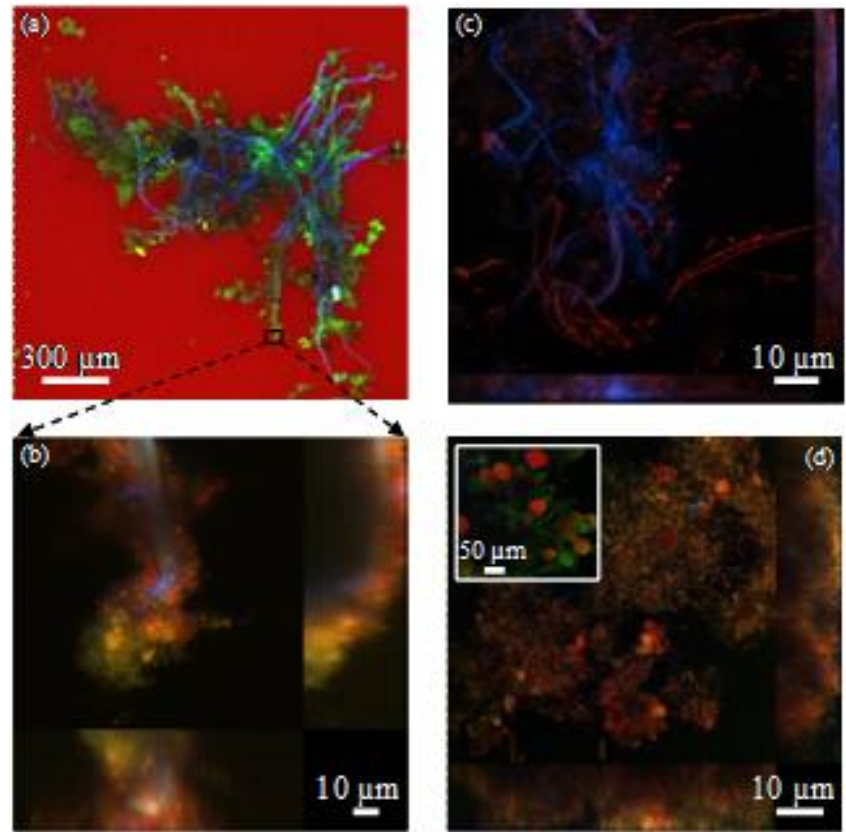

Figure 5: (a) 2D optical image of a suspended matter floc (objective $\times 4$, zoom 1.5). (b) Detailed investigation of a zone from figure $a . x y, x z$ and $y z$ projections of CLSM stack optical sections (objective $\times 60$, zoom 1.7). Blue: cellulose fiber, green: bacteria and red: extracellular polymeric substances (EPS). (c) $x y, x z$ and $y z$ projections of CLSM stack optical sections (objective $\times 60$, zoom 3), showing 


\section{International Journal of Science and Research (IJSR) \\ ISSN (Online): 2319-7064}

Index Copernicus Value (2015): 78.96 | Impact Factor (2015): 6.391

cellulose fibers (blue) surrounded by filamentous bacteria (red). (d) $x y, x z$ and $y z$ projections of CLSM stack optical sections (objective $\times 60$, zoom 3). Detached and suspended fragment from bacterial biofilm contains bacteria, EPS and fungi (inset Fig. d).

Structural characterizations of resin-embedded SM by TEM (25 observations) confirm and complete CLSM investigations. Figure 6 illustrates a typical example of obtained micrographs. SM mainly contain cellulose fibers and microbial biomass (Fig. 6a). The cellulose matrix trapped dead and livingbacteria, cell lyses material and organo-mineral particles ${ }^{[20,21]}$. Detailed observations at nanometric scale showed an interaction between microorganisms and cellulose fibers (Fig. 6b). Bacterial cellsbiodegrade cellulose fibers and the resulting detritus are spread in the bacteria/cellulose interaction zones ${ }^{[21]}$. Thus, in addition to their role as skeleton, cellulose fibers can be used as carbon source by adherent bacterial cells to ensure their growth.
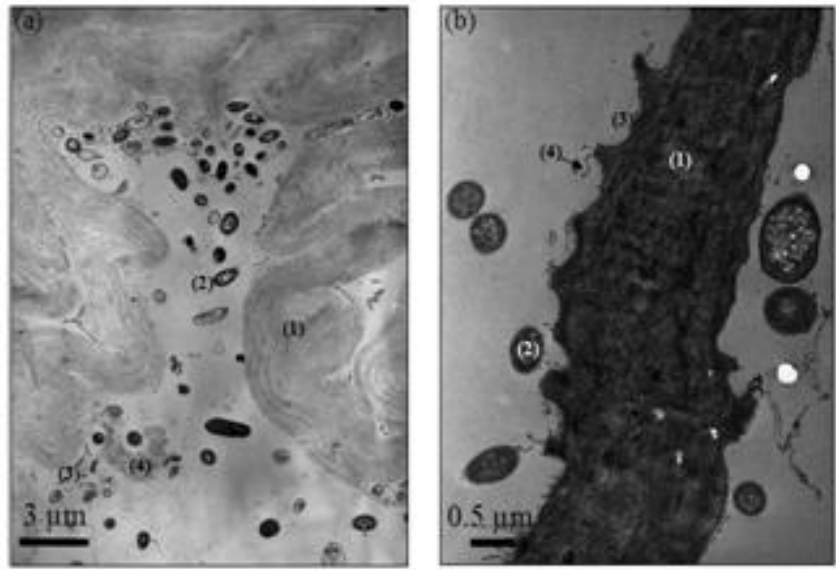

Figure 6: TEM micrographs of thin stained sections of resin-embedded suspended matter. (a) Non-altered cellulose

fibers (1), bacterial cells (2), cell lyses material (3) and inorganic matter (4). (b) Biodegraded cellulose fiber (1), bacteria (2), bacteria/cellulose interaction zones (3) and biodegradation detritus (4)

\section{6) Microscopy speciation of sewer biofilms}

TEM and CLSM observations of bacterial biofilms showed that they have similar composition than SM (EPS, bacteria, cellulose fibers). Whereas, they have very different structures and 3Darchitectures.

The structures of three bacterial biofilms were characterized following 12 CLSM observations. Figures 7a, 7b, 7c (objective $\times 40$, zoom 1 ) and $7 \mathrm{~d}$ (objective $\times 40$, zoom 1.5 ) illustrate typical projections at $\mathrm{z}$-axis (central image), y-axis (bottom image), and x-axis (right image) of optical sections. CLSM observations (Fig. 7a) showed that bacterial biofilms were mainly composed of a large amount of EPS matrix (in red) in which bacterial cells are enclosed ${ }^{[43,44]}$ (in green) andBiofilm surface is covered by filamentous cells (inset Fig. 7a).

The coverage surface of sewer biofilm is $92 \%$ and its porosity is 0.55 . Thus, biofilm is more compact and denser than suspended matter (coverage surface $45 \%$, SM porosity 0.79 ).
Furthermore, large amount of cellulose fibers was identified within the biofilm and deposited at its surface (Fig. 7b). Figure 7c (x and y projections) shows fibers in the depth of the biofilm. Thus, cellulose fiber may settle from sewage on the biofilm surface and they are later embedded by the EPS matrix during biofilm growth.

Detailed CLSM investigations (Fig. 7d) identifiedseveral holes within the biofilm, corresponding to water channels with an average width of $30 \pm 15 \mu \mathrm{m}$ at the top of the biofilm. The size of these holes decreases with depth, leading to a more compact and denser biofilm near the pipe wall ${ }^{[42]}$.Water channels are involved in the nutrition and matter transfer within the biofilm ${ }^{[46,47]}$. Open channels are connected to the bulk liquid, and can enhance the rate of substrate diffusion by facilitating convection when the mass transfer boundary layer closely follows the irregular biofilm surface $^{[48]}$.
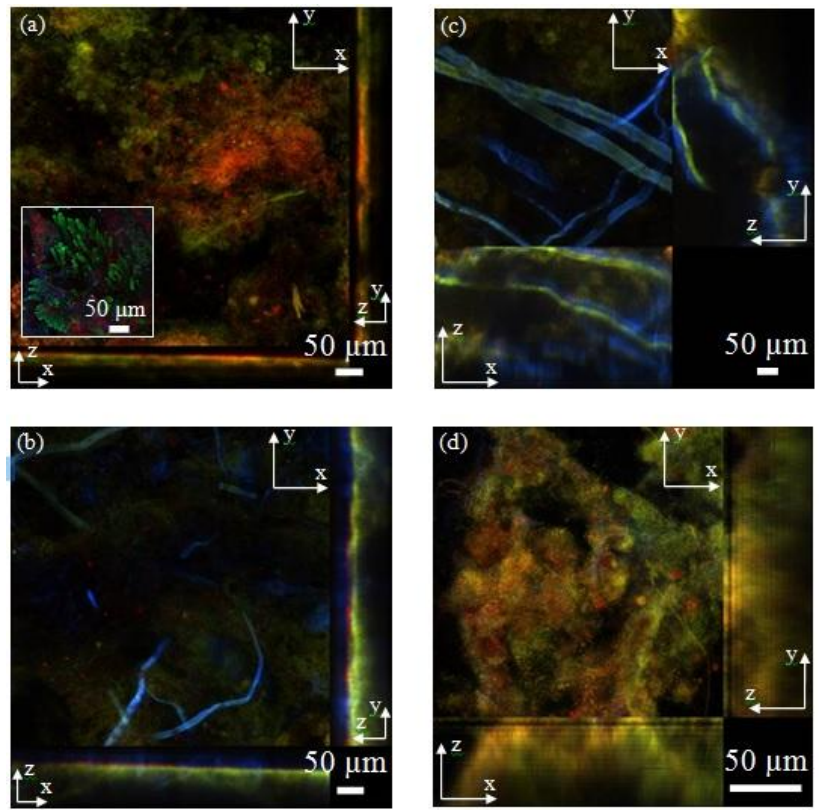

Figure 7: Typical xy, xz and yz projections of CLSM optical sections of bacterial biofilm stained with AcridineOrange. Green: bacteria, red: EPS and blue: cellulose fibers. (a) Observation using objective $\times 20$ and zoom 1. Biofilm surface covered by filamentous cells (inset Fig. a, biofilm stained by live/dead fluorochrome). (b) objective $\times 20$, zoom 1,cellulose fibers deposit at biofilm surface. (c) objective $\times$

20, zoom, cellulose fibers embedded in EPS matrix. (d) objective $\times 40$, zoom 1.5 , water channels within the biofilm.

Moreover, figure 8 illustrates the depth profile of biofilm areal porosity. At the biofilm top, areal porosity is high (0.8), with a patchy layer at the contact surface with wastewater.Areal porosity decreases with depth to reach 0.35 , giving a denser biofilm. Marjaka (2003) has found that bacterial biofilm was composed of fours layers ${ }^{[15]}$ : the bulk water phase, the heterogeneous non-dense layer, the dense layer and the porous bed (substratum). Several factors may influence the structure of biofilm in sewer system such as $\mathrm{Po}_{2}$ and flow velocity ${ }^{[49]}$. Studying the nitrification capacity of sewer system, Æsøy (1998) showed that biofilm grown under anoxic condition was brownish, fluffy, porous, uneven 


\section{International Journal of Science and Research (IJSR) \\ ISSN (Online): 2319-7064 \\ Index Copernicus Value (2015): 78.96 | Impact Factor (2015): 6.391}

and contained gas bubbles ${ }^{[17]}$. While, in septic condition biofilm was black, grainy, compact and thin.

The similar composition of SM and sewer biofilms suggests that there is an equilibrated exchange between these two compartments. SM may deposit at the surface of biofilms, thus contributing to the biofilm development. Whereas, under shear stress and at mature state, some parts of the biofilmmay be detached and suspended inwastewater ${ }^{[41]}$.

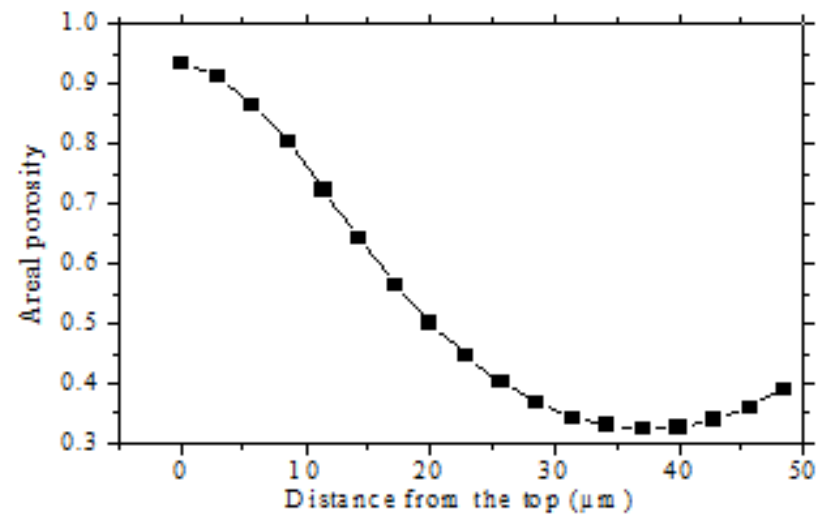

Figure 8: Areal porosity profile from the top to the bottom of bacterial biofilm

Forty five TEM micrographs were carried out on five resinembedded biofilm. Figure 9a illustrates a typical micrometer scale observation. The distribution of bacterial cells is heterogeneous ${ }^{[21]}$, with a much denser bacterial zone in the left of micrograph. Some bacteria had an elongated shape, with 1-3.5 $\mu \mathrm{m}$ of length and 0.5-1.5 of diameter. Circular shape bacteria were also observed, but they may correspond to a vertical slice of elongated bacteria. Several microorganisms with division septum were identified, showing bacterial cells in division phase, and the contribution of cell division intobiofilm growth. Wanner and Gujer (1985) showed that bacterial cells grow within the biofilm and displace other biofilm components perpendicularly to the substratum ${ }^{[50]}$. In addition, Chen (2003) indicated that biofilm in gravity sewer contained a high ATP level and was very active ${ }^{[51]}$.

TEM observations at the nanometric scale (Fig. 9b) showed that the space between bacterial cells contained EPS matrix and some mineral particles ${ }^{[21]}$. A previous chemical speciation of these biofilms showed that they contain heavy metal-bearing particles including alloys and metal fragments, oxidized metals and sulfides ${ }^{[10]}$. These formers diffuse from bulk water into biofilm matrix ${ }^{[52]}$.TEM investigations of bacterial cytoplasm indicate the presence of polyphosphate grains and ovoid white bubbles that may be lipid reserves (Fig. 9b).

Furthermore, EPS matrix contains microbial detritus (Cell wall) spread in the intercellular space (Fig. 9c), resulting from cell lyses ${ }^{[21]}$. Bacterial destruction may be due to the presence of some bacteriophage-like viruses (hexagonal capside) within the biofilm (inset Fig. 9e). In fact, chains of viruses were frequently identified entrapped within the EPS network(Fig. 9d). They have an average size of $80 \mathrm{~nm}$ and some of them are located adjacent to bacterial cells (Fig. 9e).
Few studies have been carried out to examine the colocalisation of microorganisms and viruses in sewer biofilms. Biofilms was used as biological barriers to remove viruses from wastewater. Viruses were adsorbed to bacterial cells and EPS ${ }^{[53]}$. Moreover, a previous study showed that $\varphi \mathrm{X} 174, \mathrm{MS} 2$ and B40-8, and poliovirus-1 phages (mean size 24-30 $\mathrm{nm}$ ) are able to attach an artificial biofilm in a drinking-water distribution system ${ }^{[54]}$. Some phages had polysaccharide-degrading enzymes, leading to cells lysis and a rapid destruction of the biofilm ${ }^{[55]}$.

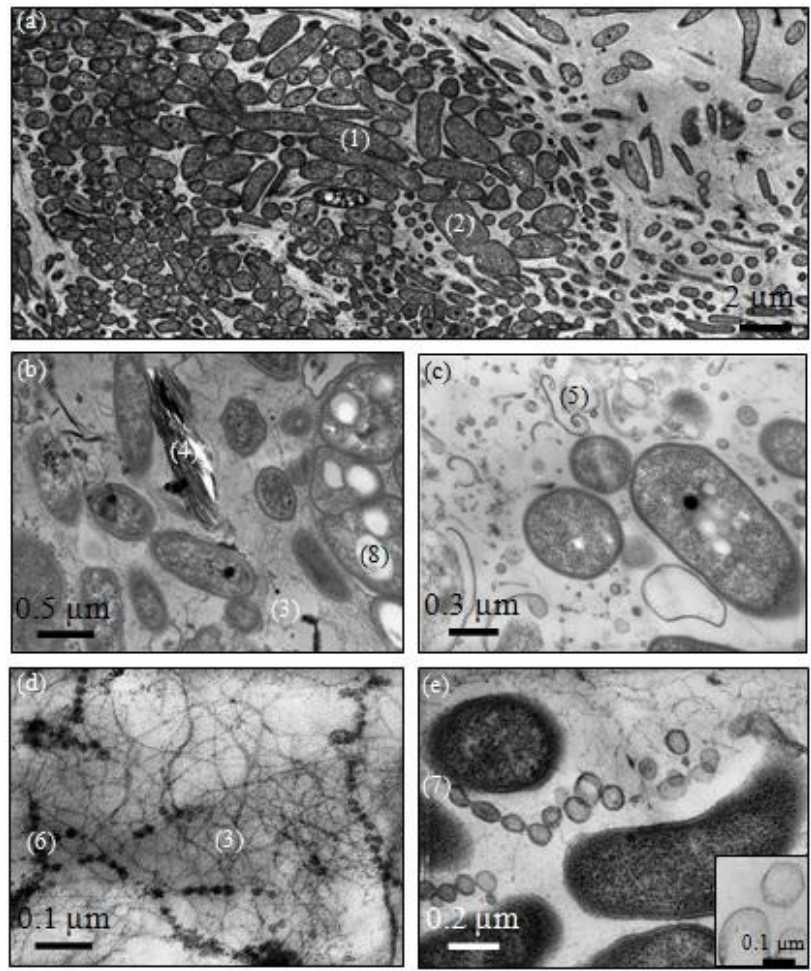

Figure 9: Typical TEM micrographs of bacterial biofilm, thin stained sections of resin-embedded biofilm. (a) micron scale showing a heterogeneous bacterial distribution (1) and microorganisms in division phase (2). space between cells contains EPS (3), mineral particles (4), cell detritus (5) and chain viruses (6). (e) Viruses in contact with bacteria wall. Some of these viruses are hexagonal bacteriophages (inset

Fig. e). Bactria cytoplasm contains lipid reserves (8).

Thus, bacterial biofilm may be considered as a micro-niche in which viruses are concentrated. In our case, sewer biofilm may concentrate viruses originated from human excretion such as Levivirus and Allolevivirus and may be considered as a potential source of river pollution by pathogenic viruses, especially during combined sewer overflows ${ }^{[56]}$.

\section{Conclusion}

The results of the present study indicate that the concentrations of DOC decrease from the upstream to the downstream of sewer pipes. This decrease may be due to the assimilation of DOC by sewage bacteria or to a simple dilution by the infiltration of unpolluted water (groundwater or rainwater percolation) into collectors through wall crucks. The decrease of TSS, VM and particle size distribution along the sewer is originated mainly from the sedimentation of SM towards downstream, even if cellulose biodegradation

\section{Volume 6 Issue 7, July 2017 www.ijsr.net}




\section{International Journal of Science and Research (IJSR) \\ ISSN (Online): 2319-7064}

Index Copernicus Value (2015): 78.96 | Impact Factor (2015): 6.391

by attached clusters was shown by TEM.The total number of bacterial cells in sewage doesn't evolve along the sewer, due to a high food/microorganisms ratio in wastewater.

TEM and CLSM observations indicate that bacterial biofilms and SM have similar composition (EPS, bacteria, cellulose fibers, inorganic particles). Whereas, they have very different structure and $3 \mathrm{D}$ architecture, $\mathrm{SM}$ is a patchy biological aggregate (SM porosity 0.8 ) in which cellulose fibers are skeleton for bacterial adhesion and cluster formations. In contrast, sewer biofilm structure appears more compact and denser (biofilm porosity 0.55 ) than SM, and cellulose fibers are embedded within biofilm EPS matrix. Furthermore, a dynamic exchange was identified between SM and biofilms,SM may deposit at the surface of biofilms and contribute to the biofilm development. Likewise, under shear stress and at mature stage, some part of biofilms may be detached and suspended into wastewater. Moreover, TEM investigations of sewer biofilms showed that they entrap and concentrate viruses circulating in sewage and may be considered as a potential source of river pollution by pathogenic viruses, especially during combined sewer overflow.

\section{References}

[1] Warith, M.A., Kennedy, K., Reitsma, R. (1998) Useof sanitary sewers as wastewater pre-treatmentsystems. Waste Mang. 18, 235-247.

[2] Hvitved-Jacobsen, T., Vollertsen, J., Matos, J.S. (2002) Thesewer as a bioreactor - A dry weather approach.Wat. Sci. Technol. 45(3), 11-24.

[3] Tanji Y., Sakai R., Miyanaga K., Unno, H. (2006) Estimation of self-purification capacity of biofilmformed in domestic sewer pipes. Biochem. Eng. J. 31, 96-101.

[4] Vollertsen, J., Revilla, N., Hivitved-Jacobsen, T., Nielsen, A. H. (2015) Modeling sulfides, pH and hydrogen sulfide gas in the sewers of San Francisco. Water Environ. Res. 87 (11), 1980-1989.

[5] Raunkjær K., Hvitved-Jacobsen T., Nielsen P.H. (1995) Transformation of organic matter in a gravity sewer. Water Environ. Res. 67(2), 181-188.

[6] Chen, G.H., Leung, D.H.W., and Huang, J.C. (2001) Removal of dissolved organic carbon in sanitary gravity sewer. J. Environ. Eng. 127(4), 295-301

[7] Huisman, J.L., Gasser, T.,Gienal, C., Kühni, M., Krebs, P., Gujer, W. (2004) Quantification of oxygen fluxes in a long gravity sewer. Water Res. 38, 1237-1247.

[8] El Samrani, A.G., Lartiges, B.S., Ghanbaja, J., Yvon, J. Kohler, A. (2004) Trace element carriers in combined sewer during dry and wet weather: an electron microscope investigation. Water Res. 38, 2063-2076.

[9] Zhang, L., De Schryver, P., De Gusseme, B., DeMuynck, W., Boon, N., Verstraete, W. (2008) Chemical and biological technologies for hydrogensulfide emission control in sewer systems: A review.Water Res. 42, 1-12.

[10] Houhou, J., Lartiges, B.S., Montarges-Pelletier, E.,Ghanbaja, J., Kohler, 1.(2009) Sources, nature, and fate of heavy metal-bearing particles in the sewer system. Sci. Total Environ. 407, 6052-6062.
[11] Jahn, A., Nielsen, P.H. (1998) Cell biomass and exopolymer composition in sewer biofilm. Wat. Sci. Technol. 37(1), 17-24.

[12] Cydzik-Kwiatkowska, A., Zielinska, M. (2016) Bacterial communities in full-scale wastewater treatment systems. World L. Microbiol.Biotechnol.32, 66.

[13] Tanaka N., Hvitved-Jacobsen, $\quad T$. (1998)Transformations of wastewater organic matterinsewers under changing aerobic/anaerobic conditions. Wat. Sci. Technol. 37 (1), 105-113

[14] Özer A., Kasirga E. (1995) Substrate removal in long sewer lines. Wat. Sci. Technol. 31(7), 213-218.

[15] Marjaka, I.W., Miyanaga, K., Hori, K., Tanji, Y., Unno, H. (2003) Augmentation of self-purification capacity of sewer pipe by immobilizing microbes in the pipesurface. Biochem. Eng. J. 15, 69-75.

[16] Baban, A., Talinli, I. (2009) Modeling of organic matter removal and nitrification in sewer systems-an approach to wastewater treatment. Desalination 246 (1-3), 640647.

[17] Æsøy, A., Storfjell, M., Mellgren, L., Helness, H., Thorvaldsen, G., Ødegaard, H., Bentzen, G. (1997) A comparison of biofilm growth and water quality changes in sewer with anoxic and anaerobic (septic) conditions. Wat. Sci. Technol. 36(1), 303-310

[18]Cao, Y.S., Alaerts, G.J. (1995) Aerobic biodegradationand microbial population of a synthetic wastewater in a channel with suspended and attached biomass.Wat. Sci. Technol. 31(7), 181-189.

[19] Rocher, V., Azimi, S., Moilleron, Chebbo, G. (2003) Biofilm in combined sewers: wet weather pollution source and/or dry weather pollution indicator? Water Sci. Techno. 47 (4), 35-43.

[20] Houhou, J., Lartiges, B.S., Hofmann, A., Frappier, G., Ghanbaja, J., Temgoua, A. (2009) Phosphate dynamics in an urban sewer: a case study of Nancy, France. Water Research. 43(4) 1088-1100.

[21] ElKhatib, R., Lartiges, B.S., El samrani,A.,Faure, P., Houhou, J., Ghanbaja, J. (2012) Speciation of organic matter and heavy metal in urban wastewater from an emerging country. Water Soil Air Pollution 223(8), 4695-4708.

[22] Solé, A., Gaju, N., Méndez-Álvarez, S., Esteve, I. (2001) Confocal laser scanning microscopy as a tool to determine cyanobacteria biomass in microbial mats. $\mathrm{J}$. Micros. 204(3), 258-262.

[23] Surman, S.B., Walker, J.T., Goddard, D.T., Morton, L.H.G., Keevil, C.W., Weaver, W., Skinner, A., Hanson, K., Caldwell, D., Kurty, J. (1996) Comparison of microscope techniques for the examination of biofilms. J. Microbiol. Methods. 25, 57-70.

[24] Chaignon, V., Lartiges, B.S., El Samrani, A.G., Mustin, C. (2002) Evolution of size distribution and transfer of mineral particles between flocs in activated sludges: an insight into floc exchange dynamics. Water Res. 36,676-684.

[25] Wirtanen, G., Salo, S., Helander, I. M., MattilaSandholm, T. (2001) Microbiological methods for testing disinfectant efficiency on Pseudomonas biofilm. Colloides Surf. B Biointerfaces. 20, 37-50.

[26] Jana-Sur, P., Chakraborty, A.K. (2005) Studies on the interaction of bacterial capsular polysaccharide- 


\section{International Journal of Science and Research (IJSR) \\ ISSN (Online): 2319-7064}

Index Copernicus Value (2015): 78.96 | Impact Factor (2015): 6.391

Klebsiella K16 with cationic dyes. J. Photochem. Photobiol. Chem. 173, 64-69.

[27] Saunders A.M. (1964). Histochemical identification of acid mucopolysaccharides with acridine orange. Journal of Histochemistry, 12:164-170.

[28] Lartiges, B.S., Deneux-Mustin, S., Villemin, G., Mustin, C., Barrès, O., Chamerois, M., Gerard, B., Babut, M. (2001) Composition, structure and size distribution of suspended particles from the rhineriver.Water Res. 35(3), 808-816.

[29] Sayed, S., Tarek, S., Dijkstra, I., Moerman, C. (2007) Optimumoperation conditions of direct capillary nanofiltration of wastewater treatment. Desalination. 214, 215-226.

[30] Wand, H., Vacca, G., Kuschk, P., Krüger, M., Kästner, M. (2007) Removal of bacteria by filtration in planted and non planted sand columns. Water Res. 41, 159-167.

[31] Houhou, J., Lartiges, B.S., France-Lanord, C., Guilmette, C., Poix, S., Mustin, C. (2010) Isotopic tracing of clear water sources in an urban sewer: a combined water and dissolved sulfate stable isotope approach Water Research. 44, 256-266.

[32] Dirckx, G., Van Daele, S., Hellinck, N. (2016) Groundwater Infiltration Potential (GWIP) as an aid to determining thecause of dilution of waste water. J. Hydrol. 542, 474-486.

[33] Nielsen P.H., Raunkjær K., Norsker N.H., Jensen N.A., Hvitved-Jacobsen, T. (1992) Transformation of wastewater in sewer systems - a review. Wat. Sci. Technol. 25(6), 17-31.

[34] Sakarbani, R., Vollertsen, Jes., Ashley, R.M., HvitvedJacobsen, T. (2009) Biodegradability of organic matter associated with sewer sediments during first flush. Sci. Total Environ. 407 (8), 2989-2995.

[35] Michelbach, S. (1995) Origin, resuspension and settling characteristics of solids transported incombined sewage. Wat. Sci. Technol. 31(7), 69-76.

[36]Lee, S., Maniquiz-Redillas, M. C., Lee-Hyung, K. (2014) Settling basin design in a constructed wetland using TSSremoval efficiency and hydraulic retention time. J. Environ. Sci. 26 (9), 1791-1796.

[37] Guan, X-Y., Chen, G-H., Shang, C. (2005) Re-use of water treatment works sludge to enhance particulate pollutant removal from sewage. Water Res. 39, 34333440 .

[38] Fugate, D., Chant, B. (2006) Aggregate settling velocity of combined sewage overflow. Mar. Pollut. Bull. 52(4), 427-432.

[39] Friedler, E., Brown, D.M., Butler, D. (1996) A study of WC derived sewer solids. Wat. Sci. technol. 33(9), 1724.

[40] Rocher, V., Azimi, S., Moilleron, R., Chebbo, G. (2003) Biofilm in combined sewers: wet weather pollution source and/or dry weather pollution indicator? Wat. Sci. Technol. 47(4), 35-43.

[41] Weber, S.D., Ludwig, W., Schleifer, K.H, Freid, J. (2007) Microbial composition and structure of aerobic granular sewage biofilms. Appl. Environ. Microbiol. 73(19), 6233-6240.

[42] Mahfoud, C., El Samrani, A., Mouawad, R., Hleihel, W., El Khatib, R., Lartiges, B.S., Ouaïni, N. (2009) Disruption of biofilms from sewage pipes under physical and chemical conditioning. J. Environ. Sci. 21 (1), 120-126.

[43] Paul, E., Carlos Ochaa, J., Pechaud, Y., Liu, Y., Liné, A. (2012) Effect of shear stress and growth conditions on detachment and physical properties of biofilms. Water Res. 46 (17), 5400-5508.

[44]Hoa P T, Nair L, Visvanathan C, 2003. The effect of nutrientson extracellular polymeric substance production and itsinfluence on sludge properties. Water SA. 29(4), 437-442.

[45] Fish, K., Osborn, A.M., Boxall, J.B. (2017) Biofilm structures (EPS and bacterial communities) in drinking water distribution systems are conditioned by hydraulics and influence discolouration. Sci. Total Environ. 593594, 571-580.

[46]Donlan, R.M. (2002) Biofilms: Microbial life on surfaces. Emerg. Infect. Dis. 8 (9), 881-890.

[47] Massol-deyá, A.A., Whallon J., Hickey R.F., Tiedje J.M. (1995) Channels structures in Aerobic biofilmsof fixed-film reactors treating contaminated groundwater. Appl. Environ. Microbiol. 61(2), 769-777.

[48] De Beer, D., Stoodley, P., and Lewandowski, Z. (1996) Liquid flow and mass transport in Heterogeneous biofilms. Water Res. 30(11), 2761-2765.

[49]Liu, T., Frank Cheng, Y., Sharma, M., Voordouw, G. (2017) Effect offluidflow on biofilm formation and microbiologically influencedcorrosion of pipelines in oilfield produced water. J. Petrol. Sci. Eng. 156, 451459.

[50] Wanner, O., Gujer, W. (1985) Competition in biofilms. Wat. Sci. Technol. 17(2-3), 27-44.[37] Chen, G.H., Leung, D.H.W., and Huang, J.C. (2003)Biofilm in the sediment phase of a sanitary gravity sewer. Water Res. 37, 2784-2788.

[51] Chen, G.H., Leung, D.H.W., and Huang, J.C. (2003) Biofilm in the sediment phase of a sanitary gravity sewer. Water Res. 37, 2784-2788.

[52] Torresi, E., Polesel, F., Bester, K., Christensson, M., Smets, B.F., Trapp, S., Andersen, H.R., Plosz, B.G. (2017)Diffusion and sorption of organic micropollutants in biofilms with varying thicknesses. Water Res. 123, $388-400$.

[53] Ueda, T., Horan, N.J. (2000) Fate of indigenous bacteriophage in a membrane bioreactor. WaterRes. 34(7), 2151-2159.

[54] Skraber, S., Schijven, J., Gantzer, C., de RodaHusman, A.M. (2005) Pathogenic viruses in drinking-water biofilms: a public health risk? Biofilms. 2, 1-13.

[55] Sutherland, I.W., Hughes, K.A., Skillman, L.C., Trait, K. (2004) The interaction of phage and biofilms. FEMS Microbiol.Lett. 232, 1-6.

[56] Ogorzaly, L., Gantzer, C. (2006) Developmznt of realtime RT-PCR methods for septic detection of FspecificRNA bacteriophage genogroups: Application to urban raw wastewater. J. Virol. Methods 138, 131-139.

\section{Volume 6 Issue 7, July 2017 www.ijsr.net}

